\title{
Partnering with the private sector to strengthen provision of contraception
}

\author{
Karen Hardee \\ Population Council \\ David Wofford \\ Nandita Thatte
}

Follow this and additional works at: https://knowledgecommons.popcouncil.org/departments_sbsr-rh

Part of the Demography, Population, and Ecology Commons, Family, Life Course, and Society Commons, Health Economics Commons, and the Health Policy Commons How does access to this work benefit you? Let us know!

\section{Recommended Citation}

Hardee, Karen, David Wofford, and Nandita Thatte. 2017. "Partnering with the private sector to strengthen provision of contraception," Family Planning Evidence Brief. Geneva: World Health Organization. 


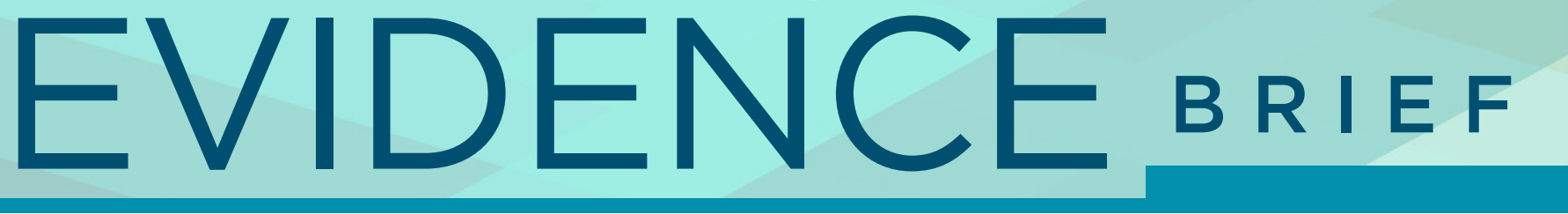

\section{Partnering with the private sector to strengthen provision of contraception}

\author{
$\rightarrow$ Family planning is most successful \\ when clients have a variety of \\ methods to choose from and a variety \\ of service delivery sites from which to \\ obtain them. (1)
}

The private sector plays a critical role in family planning (FP) and can contribute to a total market approach to providing contraceptives (2). The private sector accounts for around two-fifths of contraceptive provision worldwide (3), with the share higher in some countries; in Nigeria $60 \%$ of women obtain contraception in the private sector (4). The private sector ranges from nongovernmental and faith-based organizations, usually providing free or subsidized services, to for-profit medical providers, pharmacies and drug shops. Workplaces also offer a private sector venue for providing health services, including FP.

As countries move towards their FP2O20 goals and increase domestic resources to do so, the private sector is a critical partner (5). Among private sector service options, social marketing, social franchising, and pharmacies and drug shops most readily contribute to sustainable markets for contraceptive services. Corporate sector workplace programmes also show promise for reaching millions of women.

\section{SOCIAL MARKETING}

Social marketing uses marketing techniques to achieve behavioural change coupled with making contraceptives available through private sector outlets. It has been successful in promoting a wide range of contraceptive methods, with strong evidence showing its impact on the availability of injectables in Bangladesh, condoms in Pakistan, and Cyclebeads to support the Standard Days Method in Benin, the Democratic Republic of the Congo and Ecuador (6). Between 1990 and 2010, social marketing programmes doubled the number of couple-years of

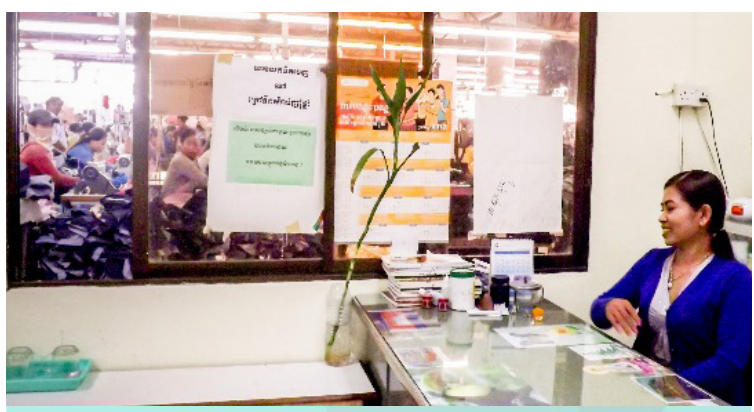

\section{POLICY AND PROGRAM CONSIDERATIONS}

$\rightarrow$ As part of a total market approach governments should ensure that regulations support private sector provision of contraceptives and that the private sector complies with public sector health standards.

$\rightarrow$ Attention to equity, quality, affordability, access, method choice, and good counselling is important to ensure that women obtaining information and contraceptives from private sector sources are making full, free and informed decisions.

$\rightarrow$ Governments could include the private sector in funding proposals to the Global Financing Facility, which leverages private sector capabilities in delivery and supply chains to improve access to family planning.

$\rightarrow$ Governments should engage industry in developing policies and programmes that expand access to family planning information, products and services in the workplace.

$\rightarrow$ Governments should explore schemes at scale for contracting, reimbursement and subsidising social marketing and social franchising networks to promote quality services and equitable, affordable access to comprehensive $\mathrm{SRH}$.

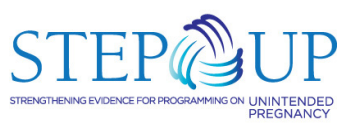


protection that they support (7). In Nigeria, sales of longacting and reversible contraceptives (LARCs) in one social marketing programme in 2015 exceeded 100,000 (8).

Social marketing taps into large networks of private providers, helps reduce geographic and socioeconomic disparities by reaching women who are young, poor and living in rural areas (9), and reaches men and boys, who are typically not well-served by health facilities (10).

\section{SOCIAL FRANCHISING}

Social franchising (11) is the provision of contraceptives in "branded" private facilities designed to expand the market for contraceptives with high-quality, cost-effective and equitable services that reach a range of population groups (12). Social franchising has produced increases in the provision of LARCs as those methods become more widely available in a number of countries, including Kenya and Nigeria (13). Social franchising attracts hardto-reach groups, including young women and low-income clients, and also successfully reaches new clients (14). Social franchised private facilities that offer prenatal and childbirth services can also increase use of postpartum family planning (15).

\section{DRUG SHOPS AND PHARMACIES}

Drug shops and pharmacies are important sources of health care, particularly in rural areas or urban slums with few public clinics (16). They are often the first stop for women and men who seek FP information or services. These two sources account for most of the private sector provision of contraception in sub-Saharan Africa, especially for condoms, pills, injectables and emergency contraception (17).

Women in Tanzania who obtain oral contraceptives from pharmacies are able to self-screen their eligibility for contraceptive use as accurately as nurses (18), and in Bangladesh, trained drug shop staff can safely and effectively provide injectables and other methods (19). Recent evidence from Nigeria shows that patent medical vendors can provide injectables safely, and so could significantly expand access to contraception in countries where such sources are widely available (20). Pharmacy supply of low-cost emergency contraception in South Africa and in many low-income countries increases access to that method (21). Pharmacies and drug shops are also convenient for adolescents, as well as for men and boys, both as sources of information and for the supply of products for themselves and their partners.

\section{WORKPLACE POLICIES AND PROGRAMMES}

Expanding access to family planning information, products and services requires a more expansive approach to how the global health community engages with the corporate sector. Multinational and national corporations and their supplier companies employ millions of women, men and young people, many of whom have left rural homes to take jobs in towns and cities. Employed urban workers have significant reproductive health $(\mathrm{RH})$ needs, and workplace clinics could be the first points of contact for FP information, counselling and referrals. Setting global standards that encourage corporations to ensure that companies and factories from which they obtain products provide access to health care, including FP/ $\mathrm{RH}$, would help reach millions of women.

Research in Cambodia found that RH and FP were the main health needs of workers, who face many barriers to services that businesses and the government can help overcome (22). As more people move to urban areas and industries develop in emerging economies, the workplace can be an important venue for changing norms, developing new networks of contraceptive users and expanding access to services. For example, the Family Guidance Association of Ethiopia, which works with more than 150 enterprises to improve health services and referrals, analysed health outcomes in one client factory over 10 years and found reductions in unintended pregnancies and STIs as well as sick leave. Uptake of contraception rose from $11 \%$ to $90 \%$ between 1997 and 2000 (23).

In 2016, a tripartite agreement between the Bangladesh Directorate General for Family Planning, the Bangladesh Garment Manufacturers Export Association and EngenderHealth Bangladesh enables BGMEA to provide training and free contraceptives to factory clinics, with the potential to reach thousands of factory workers (24).

\section{REFERENCES}

1 Shelton, JD. and C Finkle. 2016. "Leading with LARCs in Nigeria: The Stars are Aligned to Expand Effective Family Planning Services Decisively." Global Health: Science and Practice. 4(2): 179-185.

2 Barnes J, Vail J, Crosby D. Total Market Initiatives for Reproductive Health. Bethesda, MD: Strengthening Health Outcomes through the Private Sector Project, Abt Associates; 2012.

3 Campbell, OMR, L Benova, D Macleod et al. 2015. "Who, What, Where: An Analysis of Private Sector Family Planning Provision in 57 Low- and Middle-income Countries." Tropical Medicine and International Health. 20(12): 1639-1656.

4 Mitchell, S. 2013. "The Role of the Private Sector in Family Planning." Blog. November 10. http:// healthmarketinnovations.org/blog/role-private-sectorfamily-planning. Accessed June 7, 2017.

5 Santos, LA. 2016. "The case for a 'greater' private sector role in family planning." https://www.devex.com/news/ the-case-for-a-greater-private-sector-role-in-familyplanning-87714. Accessed June 7, 2017

6 High Impact Practices in Family Planning (HIP). 2013. "Social Marketing: Leveraging the Private Sector to Improve Contraceptive Access, Choice and Use." Washington, DC: USAID. https://www. fphighimpactpractices.org/sites/fphips/files/hip_sm_brief. pdf. Accessed June 7, 2017.

7 High Impact Practices in Family Planning (HIP). 2013. "Social Marketing: Leveraging the Private Sector to Improve Contraceptive Access, Choice 
and Use." Washington, DC: USAID. https://www. fphighimpactpractices.org/sites/fphips/files/hip_sm_brief. pdf. Accessed June 7, 2017.

8 Shelton, JD. and C Finkle. 2016. "Leading with LARCs in Nigeria: The Stars are Aligned to Expand Effective Family Planning Services Decisively." Global Health: Science and Practice. 4(2): 179-185.

9 Ortalyi, $\mathrm{N}$ and S Malarcher. 2010. "Equity Analysis: Identifying Who Benefits from Family Planning Programs." Studies in Family Planning. 41(2): 101-108.

10 Hardee, K, M Croce-Galis, and J Gay. 2016. "Men as Contraceptive Users: Programs, Evidence and Recommendations." Working Paper. Washington, DC: Population Council, the Evidence Project.

11 Social franchising: a blockbuster to address unmet need for family planning and to advance toward the FP2O2O goal. Glob Health Sci Pract. 2015;3(2):147-148. http://dx.doi. org/10.9745/GHSP-D-15-00155. Accessed June 7, 2017.

12 Beyeler, N, L York De La Cruz, and D Montagu. 2013. "The Impact of Clinical Social Franchising on Health Services in Low- and Middle-income Countries: A Systematic Review. PlosOne. 8(4):e60669.

13 Chatraborty, NM, M Mbondo, and J Wanderi. 2016. "Evaluating the Impact of Social Franchising on Family Planning Use in Kenya." Journal of Health, Population and Nutrition. 35(19): 1-9; Shelton, JD. and C Finkle. 2016. "Leading with LARCs in Nigeria: The Stars are Aligned to Expand Effective Family Planning Services Decisively." Global Health: Science and Practice. 4(2): 179-185.

14 Social franchising: a blockbuster to address unmet need for family planning and to advance toward the FP2O2O goal. Glob Health Sci Pract. 2015;3(2):147-148. http://dx.doi. org/10.9745/GHSP-D-15-00155. Accessed June 7, 2017.

15 Eluwa GIE, Atamewalen R, Odogwu K, Ahonsi B. Success providing postpartum intrauterine devices in private-sector health care facilities in Nigeria: factors associated with uptake. Glob Health Sci Pract. 2016;4(2):276-283. http:// dx.doi.org/10.9745/GHSP-D-16-00072.

16 Stanback, J, C Otterness, M Bekita, et al. 2011. "Injected with Controversy: Sales and Administration of Injectable Contraceptives in Drug Shops in Uganda." International Perspectives on Sexual and Reproductive Health. 37(1): 2429.

17 Campbell, OMR, L Benova, D Macleod et al. 2015. "Who, What, Where: An Analysis of Private Sector Family Planning Provision in 57 Low- and Middle-income Countries." Tropical Medicine and International Health. 20(12): 1639-1656.

18 Chin-Quee, D, et al. 2013. "Women's Ability to Self-screen for Contraindications to Combined Oral Contraceptive Pills in Tanzanian Drug Shops." International Journal of Obstetrics. 123(1): 37-41.

19 Khan TU, Malarcher S, Ahmed S, Sarker S, Arevalo M. The Blue Star Program: expanding access to injectable contraception through private sector outlets in Bangladesh. Unpublished paper; 2012.

20 Evidence Project. 2017. "Strengthening the Role of Patent Medical Vendors in the Provision of Injectable Contraception in Nigeria." http://evidenceproject. popcouncil.org/resource/strengthening-the-role-ofpatent-medicine-vendors-in-the-provision-of-injectablecontraception-in-nigeria/. Accessed June 7, 2017.

21 Anderson, D. and A. Blenkinsopp. 2006. "Community Pharmacy Supply of Emergency Hormonal Contraception: A Structured Literature Review of International Evidence." Human Reproduction. 21(1): 272-284
22 Heng, Molyaneth, Ashish Bajracharya, Chhorvann Chhea, Bandeth Ros, Sopheab Heng, and Hyunwoo June Choo. 2017. "Health Needs, Health Seeking Pathways, and Drivers of Health Seeking Behaviors of Female Garment Factory Workers in Cambodia: Findings from a Qualitative Study in Phnom Penh and Kandal Provinces" Policy Brief. Washington DC and Phnom Penh, Cambodia: Population Council, The Evidence Project. http://evidenceproject.popcouncil.org/resource/ health-needs-health-seeking-pathways-and-drivers-ofhealth-seeking-behaviors-of-female-garment-factoryworkers-in-cambodia-findings-from-a-qualitative-studyin-phnom-penh-and-kandal-provinces/. Accessed June 7, 2017.

23 IPPF. 2017. "Improving the Health and Well-being of Factory Workers. Case Study Country: Ethiopia." Unpublished.

24 BGMEA signs MoU with DGFP \& EHBhttp:// in.fashionnetwork.com/news/BGMEA-signs-MoU-withDGFP-EHB,658033.html\#.WTfwRTgm7F9. Accessed on June 7, 2017.

Authors: Karen Hardee, Population Council; David Wofford, Meridien Group International; Nandita Thatte, World Health Organization. Photo credit: Karen Hardee.

This is one of seven Family Planning Evidence Briefs prepared for the Family Planning Summit held in London on July 11, 2017. The briefs highlight evidence and provide research and programme considerations for improving access to family planning and reducing unintended pregnancy. Programme considerations are based on the expert views of the authors, who undertook desk reviews drawing on existing evidence.

\section{Family Planning Evidence Briefs}

- Accelerating uptake of voluntary, rights-based family planning in developing countries (overview)

- Ensuring adequate financing of family planning commodities and services

- Reducing early and unintended pregnancies among adolescents

- Improving family planning service delivery in humanitarian crises

- Ensuring contraceptive security through effective supply chains

- Expanding contraceptive choice

- Partnering with the private sector to strengthen provision of contraception

The authors alone are responsible for the views expressed in this article and they do not necessarily represent the views, decisions or policies of the institutions with which they are affiliated.

Family Planning Evidence Brief - Partnering with the private sector to strengthen provision of contraception: WHO/RHR/17.08

(c) World Health Organization 2017. Some rights reserved. This work is available under the CC BY-NC-SA 3.0 IGO license.

For more information, please contact: Department of Reproductive Health and Research, World Health Organization, Avenue Appia 20 , $\mathrm{CH}-1211$ Geneva 27, Switzerland

E-mail: reproductivehealth@who.int

Website: www.who.int/reproductivehealth

Twitter: @HRPresearch

This material has been funded by UK aid from the UK government; however, the views expressed do not necessarily reflect the UK government's policies.

Prepared July 2017 